\title{
Research on the Difficulties and Path of Realizing the Green Development of the Automobile Enterprises under Low Carbon Economy
}

\author{
Xiu-rong LIU \\ Tianjin Vocational Institute, 300410, Tianjin, China \\ liuxiurong6008@sina.com
}

\begin{abstract}
Key words: Low Carbon Economy;Automobile Enterprises;Green Development
Abstract: There are still many difficulties in realizing the green development of the automobile enterprises under the low carbon economy.In this paper,The author analyses the difficulties of realizaing the green development, and finds out the path of achieving the green development of the automobile enterprises under low carbon economy, Which includes five aspects, Namely: To strengthen the value idea of the low carbon production and green development; To input the green production factors ;Continuously to improve the technical level of low carbon production of the automobile enterprises; Vigorously to develop and use the energy of low carbon; To construct the evaluation index system of the green development,To monitor the status of enterprise's green development in real time, and To control the development trend of the green development in time. The automobile enterprises will truly realize the unification of environmental benefits, social benefits and economic benefits through realizing the green development .
\end{abstract}

\section{The Necessity and Urgency of Realizing the Green Development of the Automobile Enterprises} under Low Carbon Economy

Facing of serious environmental pollution of increasing, increasing resource shortages, every aspect of human social life will face more significant threats and challenges[1] .For the automobile enterprises, should change a large number of long-term follow consumption of resources and energy and rely on some of the remedies measures to protect the environment; rely on the traditional model to promote economic growth in order to fundamentally solve the environmental problem. The method of solution is to achieve the green development.but, Many enterprises have some problems in the process of realizing the green development at present.Only these problems are solved, The automobile enterprises can realize the green development.

\section{The Difficulties of Realizing the Green Development of the Automobile Enterprises under Low Carbon Economy}

First,the formation of the value idea of the green development of the automobile enterprises

Realizing the green development of the automobile enterprises is a comprehensive problem, but The value of the green development of the automobile enterprises is the difficulty problem that restricts the development of enterprises.including the idea of low carbon economy, the concept of social responsibility, staff training, implementation of environmental standards and so on. The automobile enterprises are how to set up the coordination of the automobile enterprises with low carbon economy, How to take social responsibility in the development of low carbon economy, In production, the strict implementation of environmental standards and less production of carbon emissions and improve the utilization of carbon emissions of the automotive products and so on. These have become difficultics. to realize the green development of the automobile enterprises under low carbon economy. 


\section{Second,the input of the green production factors in production}

At present, the problem of the input of the production factors is mainly reflected in the raw materials of the input.these raw materials have not been fully utilized;and These raw materials of the input contain toxic substances.In the production of material conversion, the production factors are often discarded as a waste, or These raw materials can be not fully utilized.The production process and the use of the product will be toxic or pollution. Therefore, the production factors that the automobile enterprises are how to carry out the investment have become a difficult problem of the green development.

\section{Third,Control of low carbon technology in the automobile enterprises}

The development and application of low carbon technology have a great impact on the development of low carbon economy[2]. Through the development of low carbon technology, the automobile enterprises can effectively reduce energy consumption, reduce $\mathrm{Co}_{2}$ emissions. However, at present, the development and application of low carbon technology in automobile enterprises are relatively insufficient,It has affected the development of low carbon production of the automobile enterprises,so It has become a difficult problem of the green development.

\section{Fourth,the Energy of high consumption and high investment}

At present, the energy consumption in the automobile industry is high, the high consumption and high investment of energy has seriously polluted the environment. And has brought a series of problems, so It has become a difficult problem for the green development of the automobile enterprises.

\section{The Automobile Enterprises Realize the Path of the Green Development under low carbon economy}

First,strengthen the value idea of the low carbon production and the green development

The automobile enterprises should firmly establish the value idea of the coordination with low carbon economy to realize the green development. so That all staff feel that the green development is to carry out the green production;Green production can improve the environment. automobile enterprises are the main body of carbon emissions, Enterprises should take social responsibility in the development of low carbon economy..In the production of products, The automobile enterprises should strictly implement the environmental standards, and should produce the automotive products of carbon emissions less and of improving the utilization rate of carbon emissions, Quality products will reduce carbon emissions, environmental pollution; save energy and raw materials; protect environment and ecology.enterprises should increase the green production training and education efforts. By strengthening energy saving and less waste discharge aspects of education, the automobile enterprises increase staff awareness of energy and environment, strictly implement environment standards in the work.

\section{Second,investment the green production factors}

The green development is reflected in the input of production factors. that is to say, The raw materials and energy can be fully utilized and have rarely produce pollution and waste.

First of all, materials and requirement of investment is to be fully utilized in production. Large amount of raw materials used in production are usually only a small amount of substance which is required in production, as a large part of the remaining so-called "impurities" in the production of the material conversion and often discarded as waste, raw materials could not be fully utilized. If we use more pure raw materials, there is the less impurities, so resource utilization is high. secondly, raw materials of investment is free of toxic substances. Many materials which contain some toxic substances are used in the production process, so product often produce toxic and pollution. The green 
production should eliminate from the toxic raw materials and energy through technical analysis, use of non-toxic or low toxic materials.

Utilization rate of waste discharge mainly refers to the production index of the waste water and the recycling rate of waste water;Waste gas production index and recycling utilization rate; Solid waste generation and recycling rate.

The green brand products is conducive to efficient use of resources. in the whole process of the use of production and disposal,It does not produce harmful effects of products.

\section{Third,continuously to improve the technical level of production of the automobile enterprises enterprises under low carbon}

Green production processes should ensure the use of clean fuels, so that energy consumption per unit of product and material consumption per unit of product would be reduce to a minimum and parts would be easy to disassemble.first of all, We must do waste reduction, through improving production technologies and processes; using

Advanced equipment and scientific management to improve utilization of raw materials so that raw materials transform into products as much as possible to minimize the amount of waste ; Secondly, waste recycling.it is to utilize waste in the production processes, the production of resources transformed into resource of further production, turn waste into treasure; Thirdly,harmless waste.it is to reduce or eliminate the Waste toxicity of the production process, so that it does not harm the environment and humans.

\section{Fourth,vigorously develop and use low carbon energy}

On the one hand, the automobile enterprises can develop renewable energy, save the consumption of coal and other resource, and make energy used of sustainable[3].

On the other hand, the automobile enterprises can use low carbon energy, reduce energy consumption; the automobile enterprises can also use the new energy, the using of new energy sources in all sectors of automotive manufacturing. Such as new energy battery, spare parts, vehicle manufacturing and so on.

Energy intensity reflects the economic benefits of energy use. enterprises can press the required energy consumption per unit of production calculations. With the adoption of new technology of the automobile enterprises, the adoption of new technology, and striving to decline in energy intensity continually.

Fifth,to construct the evaluation index system of the green development,to monitor the status of the green development of the automobile enterprises in real time, and to control the development trend of the green enterprises in time

The green production evaluation index system of the automobile enterprises will be that all the difficulties constitute a complete green production evaluation index system, as shown in Table 1 . The indicator system will be all the factors which are divided into three levels, a total of 18 indicators, constitute a complete green production evaluation index system[4], and it use fuzzy AHP comprehensive evaluation, which can evaluate the situation of green production for the automobile enterprises to conduct comprehensive evaluation. By calculating the normalized blur synthesized and have:

$\mathrm{B}=\mathrm{WoR}=\left(\mathrm{b}_{1}, \mathrm{~b}_{2}, \mathrm{~b}_{3}, \mathrm{~b}_{4}, \mathrm{~b}_{5}\right)=($ very good, good, average, poor, very poor $)$

Specific calculation process (omitted)

According to evaluation results for the automobile enterprises to conduct comprehensive evaluation of green production. If the comprehensive evaluation results is the poor or very poor, it is indicated that the automobile enterprises have been problems of green production.So,the automobile enterprises need to respond in time according to the assessment results, find out the best way of the green development, develop green production measures and countermeasures in order to achieve green production for difficulties of the existing in the assessment; If the result is a very good or good, 
it is indicated that the green production is in good condition, the current situation is conducive to the green development of the automobile enterprises; If comprehensive evaluation result is normal,it should arouse attention to senior leaders of corporate and timely attention to the changing trends of various factors in the process, and adjust according to changes in trends. once there is unfavorable factors to green production, the automobile enterprises should take immediate and effective measures to avoid unnecessary losses.

\section{Conclusion}

The green production is energy conservation, improving energy efficiency and pollution prevention best combine way. The author analyses the difficulties of realizaing the green development and finds out the path of achieving the green development of the automobile enterprises under low carbon economy by Dynamic evaluation, To discover problems in time and Timely adjust the problem in time.The automobile enterprises will truly realize the unification of environmental benefits, social benefits and economic benefits. through realizing of the green development.

Table 1The comprehensive evaluation index system of the green development of the enterprises

\begin{tabular}{|c|c|c|c|c|c|c|c|}
\hline \multirow{19}{*}{$\begin{array}{l}\text { Comprehensive } \\
\text { evaluation of } \\
\text { enterprise green } \\
\text { development } \\
\text { A }\end{array}$} & \multicolumn{2}{|c|}{ index $\quad$ Comment } & \multirow{2}{*}{ best } & \multirow{2}{*}{$\begin{array}{l}\text { better } \\
\text { better }\end{array}$} & \multirow{2}{*}{$\begin{array}{l}\text { normal } \\
\text { normal }\end{array}$} & \multirow{2}{*}{ bad } & \multirow{2}{*}{$\begin{array}{l}\text { worst } \\
\text { worst }\end{array}$} \\
\hline & \multirow{4}{*}{$\begin{array}{l}\text { The } \\
\text { formation of } \\
\text { the value of } \\
\text { the green } \\
\text { development } \\
\mathrm{B}_{1}\end{array}$} & $\begin{array}{l}\text { the concept of the green } \\
\text { development } \mathrm{C}_{11}\end{array}$ & & & & & \\
\hline & & $\begin{array}{l}\text { Social responsibility of the } \\
\text { green development } \mathrm{C}_{12}\end{array}$ & best & better & normal & bad & worst \\
\hline & & $\begin{array}{l}\text { Staff training of the green } \\
\text { development } \mathrm{C}_{13}\end{array}$ & best & better & normal & bad & worst \\
\hline & & $\begin{array}{l}\text { Implementation of } \\
\text { environmental standards of } \\
\text { the green development } \mathrm{C}_{14}\end{array}$ & best & better & normal & bad & worst \\
\hline & \multirow{4}{*}{$\begin{array}{l}\text { Investment } \\
\text { of green } \\
\text { production } \\
\text { factors } \\
\mathrm{B}_{2}\end{array}$} & $\begin{array}{l}\text { the ecological impact of the } \\
\text { green production } \mathrm{C}_{21}\end{array}$ & smallest & small & normal & large & largest \\
\hline & & $\begin{array}{l}\text { Renewable of raw material } \\
\qquad \mathrm{C}_{22}\end{array}$ & easiest & easy & normal & hard & $\begin{array}{l}\text { difficul } \\
t\end{array}$ \\
\hline & & Recyclable of the waste $C_{23}$ & easiest & easy & normal & hard & difficul \\
\hline & & $\begin{array}{c}\text { Utilization of raw } \\
\text { materials }_{24}\end{array}$ & highest & high & normal & low & lowest \\
\hline & \multirow{2}{*}{$\begin{array}{c}\text { Developmen } \\
\mathrm{t} \text { and } \\
\text { investment } \\
\text { of low } \\
\text { carbon } \\
\text { energyB }_{3} \\
\end{array}$} & $\begin{array}{l}\text { The use of new energy } \\
\text { sourcesC } C_{31}\end{array}$ & all & more & normal & small & unuse \\
\hline & & Energy intensity $C_{32}$ & lowest & low & normal & high & highest \\
\hline & \multirow{4}{*}{$\begin{array}{c}\text { Investment } \\
\text { of } \\
\text { production } \\
\text { technologyof } \\
\text { low carbon } \\
\mathrm{B}_{4}\end{array}$} & $\begin{array}{l}\text { Energy consumption per unit } \\
\text { productC }_{41}\end{array}$ & lowest & low & normal & high & highest \\
\hline & & $\begin{array}{c}\text { Material consumption per } \\
\text { unit productC } 42 \\
\end{array}$ & lowest & low & normal & high & highest \\
\hline & & $\begin{array}{l}\text { Utilization rate of waste } \\
\text { dischargeC } \mathrm{C}_{43}\end{array}$ & highest & high & normal & low & lowest \\
\hline & & $\begin{array}{c}\text { Comprehensive utilization of } \\
\text { resources } \mathrm{C}_{44} \\
\end{array}$ & highest & high & normal & low & lowest \\
\hline & \multirow{4}{*}{$\begin{array}{l}\text { Benefits of } \\
\text { green } \\
\text { production } \\
\text { B }_{5}\end{array}$} & green brand products $\mathrm{C}_{51}$ & cleanest & clean & normal & bad & worst \\
\hline & & Environmental Benefits $\mathrm{C}_{52}$ & highest & high & normal & low & lowest \\
\hline & & Social benefit $\mathrm{C}_{53}$ & highest & high & normal & low & lowest \\
\hline & & Economic benefits $\mathrm{C}_{54}$ & highest & high & normal & low & lowest \\
\hline
\end{tabular}




\section{References}

[1] gang Fan.The Development towards Low Carbon.China and the World,China Economic Publishing House, 2010. In Chinese

[2] jin Xia.The Study on the Constraints and Countermeasures of Technological Innovation of China's Development under Low Carbon. Economy.Journal of Wuhan University of Technology(Social Science Edition), 2012(02).In Chinese

[3] hanguo XU, guoan Yang. The Turning of Green.China Low Carbon Development, China Electric Power Press, 2010.In Chinese

[4] fubing Ren,etc. Constructing Evaluation Index System of Low Carbon Society.Journal of Jianghuai Forum,2010(01). In Chinese 